\title{
PEMANFAATAN LIMBAH UDANG PADA PETERNAKAN ITIK LAYER GUNTUNG MANGGIS KOTA BANJARBARU
}

\author{
Tintin Rostini ${ }^{1}$ dan Danang Biyatmoko ${ }^{2}$ \\ ${ }^{1}$ Jurusan Peternakan, Fakultas Pertanian, Universitas Islam Kalimantan \\ ${ }^{2}$ Jurusan Peternakan, Fakultas Pertanian, Universitas Lambung Mangkurat \\ E-mail : tintin_rostini@yahoo.com
}

\begin{abstract}
ABSTRAK
Telur itik diyakini masyarakat memiliki kandungan gizi lebih baik terutama kualitas proteinnya. Tujuan dari kegiatan ini adalah untuk meningkatkan mutu atau kualitas pakan limbah udang, meningkatkan efisiensi waktu simpan atau daya simpan pakan fermentasi, meningkatkan pendapatan peternak itik layer dan dapat meningkatkan skill peternak itik dalam teknologi pengolahan pakan . khalayak saran yang digunakan adalah kelompok mitra peternak itik layer. Metode yang dilakukan terdiri dari : 1). Pelatihan, dilakukan selama 2 hari menggunakan modul pelatihan 2). Penyuluhan model PRA (Participatory Rural Appraisal), 3). Curah Pendapat (Brain storming), 4).Demonstrasi pembuatan limbah udang fermentasi (demo), menggunakan materi bahan limbah udang. 5). Kajian hasil pakan fermentasi dan 6). Evaluasi dan Monitoring Hasil (Monev). Evaluasi keberhasilan kegiatan dilakukan dengan beberapa indikator yang dibuat sebelum pelaksanaan kegiatan, disusun berdasarkan kriteria yang diperoleh pada saat survei awal kegiatan 1 bulan sebelum kegiatan demo dijalankan. Hasil kegiatan menunjukkan adanya peningkatan kemampuan skill peternak, dan Tekhnologi fermentasi mampu meningkat kualitas nutrisi limbah udang fermentasi utamanya protein murni dalam single cell protein sebagai Protein Kasar (PK) yang meningkat dari $10.36 \%$ menjdi $14.04 \%$ dengan menurunkan bahan kering (BK) dari $80.16 \%$ menjadi $77.85 \%$ dan mampu meningkat kualitas fisik limbah udang fermentasi dari segi tekstur (lebih lunak), warna (lebih kecoklatan), bau (lebih harum) dan tidak mengandung adanya jamur patogen yang membahayakan, sehingga dapat meningkatkan efesinsi penggunaan pakan . Disimpulkan bahwa Teknologi pengolahan pakan ternak sangat diperlukan oleh peternak.
\end{abstract}

Kata Kunci : itik layer, limbah udang, fermentasi, tekstur

\section{PENDAHULUAN}

Telur itik bagi masyarakat Kalimantan Selatan (KalSel) pada umumnya mempunyai nilai ekonomis yang setara dan bahkan lebih tinggi dibandingkan telur unggas lain seperti ayam. Populasi itik tahun 2018 telah mencapai 3.101.390 ekor tersebar di tiga kabupaten utama pengembangan di HSU, HST, HSS dan sebagian di Banjarbaru serta Kotabaru. Telur itik diyakini masyarakat memiliki kandungan gizi lebih baik terutama kualitas proteinnya, terbukti laporan Biyatmoko dan Rostini (2016) kandungan protein telur itik $13 \%$ lebih 
tinggi dibanding telur ayam berkisar 11

\%. Bahkan pada tahun 2017 tercatat terdapat kenaikan konsumsi telur itik meningkat $3.90 \%$ dari tahun sebelumnya menjadi $13.838 .721 \mathrm{~kg}$ telur, sementara peningkatan produksi telur itik pada tahun yang sama meningkat $11.15 \%$ (Dinas Peternakan Kalimantan Selatan, 2018). Harga telur itik satuan yang mencapai Rp.2500 3000 / butir lebih mahal dari telur ayam ternyata juga masih diminati masyarakat, dengan kata lain telur itik memang mempunyai segmen pasar tersendiri di Kalimantan Selatan. Di sisi lain tercatat ternyata sumbangan telur itik tehadap produksi telur di KalSel tahun 2017/2018 sebesar 54,14 $\%$ lebih tinggi dari ayam ras (Statistik Peternakan Kalimantan Selatan, 2019). Hal ini menunjukkan prospek pemasaran telur itik tidak mengalami kesulitan bahkan permintaannya terus meningkat.

Permintaan akan produk itik termasuk telur saat ini sangat besar. Hal ini dikuatkan oleh permintaan produk meningkat tajam bahkan hingga ke luar pulaua). Faktor yang membantu sisi permintaan yang tinggi adalah tingginya minat beternak itik di KalSel (Rohaeni et al, 1997). Disisi lain permintaan ini akan makin berat dipenuhi oleh peternak-peternak itik di KalSel karena beban pakan yang makin tinggi untuk memenuhi kebutuhan nutrisi itik yang standar agar produksi tinggi dan stabil.

Kalimantan Selatan sebagai daerah bahari sangat besar potensi limbah lautnya termasuk limbah udang. Di daerah Pelaihari kab. Tanah Laut saja coolstorage yang ada dapat memasok 40 ton/bulan limbah udang sehingga potensinya dapat dimanfaatkan sebagai pakan ternak itik (Rostini ,et al,2014). Limbah udang mengandung komposisi nutrisi tinggi terutama sebagai sumber protein. Widodo (2002) melaporkan limbah udang mengandung protein kasar $40 \%$ dan banyak nutrien lain, sedangkan Biyatmoko (2012) melaporkan limbah udang (kepala dan cangkang) dapat meningkatkan kualitas kuning telur di atas skor 12 (grade kualitas A) skala kipas warna Roche, sehingga meningkatkan telur pantai (kuning telur pucat) menjadi telur tambak (kuning telu oranye) dengan harga lebih tinggi.

Berdasarkan kajian dan pengamatan terhadap kegiatan peternakan itik yang tersebar di desa Guntung Manggis kota 
Banjarbaru khususnya di peternakan itik layer "Franky" dan peternak itik layer pada umumnya di Kalimantan Selatan masih terlihat adanya hambatan. Permasalahan yang sering muncul di tingkat peternak dalam budidaya itik petelur adalah harga pakan terus melambung, kurang adanya teknologi pakan dan rendahnya produksi harian telur

Tujuan dari kegiatan ini adalah untuk meningkatkan mutu atau kualitas pakan limbah udang, meningkatkan efisiensi waktu simpan atau daya simpan pakan fermentasi, meningkatkan pendapatan peternak itik layer dan dapat meningkatkan skill peternak itik dalam teknologi pengolahan pakan

\section{Propil Khalayak/Kelompok Sasaran}

Kelompok sasaran dari kegiatan ini adalah home industri "Peternakan Franky" yang merupakan peternakan itik petelur. Peternakan itik layer " Franky" merupakan home industri berdiri sejak tahun 1995, berada di desa Guntung Manggis di Banjarbaru Kalimantan Selatan. Skala usaha pemilikan itik berjumlah 200 - 400 ekor dengan galur itik lokal dan persilangan (mojosari - peking). Pengalaman beternak itik berlangsung antara 10 tahun lamanya. Model usaha sudah menerapkan agribisnis dengan sangat cermat mempertimbangkan pengeluaran dan keuntungan usaha. Pengembangan usaha juga selalu menjadi wacana yang terus dilakukan dari waktu ke waktu, menyangkut perluasan kandang, jenambahan jenis-jenis itik petelur, perluasan jaringan pembelian bahan baku pakan, termasuk selalu adapted terhadap berbagai teknologi bagi peningkatan mutu pakan. Kandang itik cukup permanen dan sangat memperhatikan sanitasi dan higiene.

\section{METODE KEGIATAN}

Metode yang digunakan dalam kegiatan ini sangat komprehensif, dimana kegiatan yang dibuat dan dilaksanakan dijalankan sesuai tahapan yang runut dan membantu peternak atau peserta kegiatan memahami visi kegiatan dari awal hingga akhir berupa output produk pakan fermentasi. Metode yang dilakukan terdiri dari : 1). Pelatihan, dilakukan selama 2 hari menggunakan modul pelatihan 2). Penyuluhan model PRA (Participatory Rural Appraisal), 3). Curah Pendapat (Brain storming), 4).Demonstrasi pembuatan limbah udang fermentasi (demo), menggunakan materi bahan limbah 
udang. 5). Kajian hasil pakan fermentasi dan 6). Evaluasi dan Monitoring

Hasil (Monev). Evaluasi keberhasilan kegiatan dilakukan dengan beberapa indikator yang dibuat sebelum pelaksanaan kegiatan, disusun berdasarkan kriteria yang diperoleh pada saat survei awal kegiatan 1 bulan sebelum kegiatan demo dijalankan.

\section{HASIL KEGIATAN}

Tahap Pelatihan

(Penyuluhan

metode

Peternak

PRA,
Pada kegiatan pelatihan berupa a) kegiatan penyuluhan, dan b) curah pendapat (brainstorming) yang diadakan sebagai bekal mereka sebelum diberikan demo mesin fermentasi dan pembuatan pakan limbah udang fermentasi cukup memuaskan. Hasil kegiatan oleh mentor direspons sangat baik oleh peternak peserta kegiatan di peternakan home industri "Franky". Hasil ini diindikasikan dari antusisme pekerja dan pemilik sejak awal kegiatan, selengkapnya tersaji pada Tabel 1. di bawah ini.

Tabel 1. Rekapitulasi dari kinerja pelatihan dari pekerja dan pemilik peternakan home industri "Franky"

No Parameter Kinerja Peserta Prosentase Keterangan

(\%)

\begin{tabular}{|c|c|c|c|}
\hline 1 & $\begin{array}{l}\text { Hasil pra test kemampuan dasar dalam } \\
\text { pemahaman keilmuan dan } \\
\text { keterampilan beternak itik }\end{array}$ & $60-70$ & $\begin{array}{l}\text { Pra test awal tertulis ini } \\
\text { menjadi dasar penekanan } \\
\text { teori dan keterampilan saat } \\
\text { penyuluhan, yang } \\
\text { menunjukkan tingkat } \\
\text { pemahaman peternak adalah } \\
\text { rata-rata air atau cukup. }\end{array}$ \\
\hline 2 & Ketepatan waktu kegiatan & $90-100$ & $\begin{array}{l}\text { Rata-rata hadir } 30 \text { menit } \\
\text { sebelum jadual kegiatan }\end{array}$ \\
\hline 3 & $\begin{array}{l}\text { Kehadiran peserta dalam kegiatan } \\
\text { penyuluhan }\end{array}$ & $90-100$ & $\begin{array}{l}\text { Rata-rata hadir pada kisaran } \\
90 \%\end{array}$ \\
\hline 4 & $\begin{array}{l}\text { Kehadiran peserta dalam kegiatan } \\
\text { curah pendapat atau diskusi }\end{array}$ & $90-100$ & $\begin{array}{l}\text { Rata-rata hadir pada kisaran } \\
90 \%\end{array}$ \\
\hline 5 & $\begin{array}{l}\text { Keaktifan dalam mengemukakan ide } \\
\text { dan gagasan }\end{array}$ & $70-90$ & $\begin{array}{l}\text { Cukup baik, tetapi esensi ide } \\
\text { dan gagasan kurang tajam }\end{array}$ \\
\hline 6 & Keberanian dalam bertanya & $70-90$ & Cukup mampu untuk bertanya \\
\hline 7 & $\begin{array}{l}\text { Hasil post test kemampuan peternak } \\
\text { setelah pelatihan selesai dilaksanakan }\end{array}$ & $70-80$ & $\begin{array}{l}\text { Terjadi peningkatan } \\
\text { pemahaman }\end{array}$ \\
\hline
\end{tabular}


Berdasarkan hasil kegiatan pada Tahap Pelatihan berupa penyuluhan model PRA (partisipatif) dan curah pendapat / diskusi (braistorming) yang dilaksanakan terlihat pada Tabel 2 menunjukkan secara umum bekal pengetahuan dan skill peternak di home industri peternakan "Franky" berkisar 60-70 \% tergolong cukup untuk beternak itik petelur. Walaupun demikian pengetahuan dan skill yang mereka punya masih bersifat konvensional yang diperoleh dari pengetahuan turun temurun keluarganya sebagai peternak. Ide dan gagasan yang muncul dalam diskusi dan brainstorm yang dilaksanakan saat latihan belum banyak tersentuh dan teradopsi oleh tekhnologi baru peternakan, khususnya tekhnologi pakan ternak. Oleh karena itu masih sangat perlu untuk ditingkatkan lagi pengetahuan dan skill mereka dengan memberi pemahanam dan praktek tentang tekhnologi pakan sehingga mampu mengoptimalkan produksi telur itiknya. Tekhnologi yang mereka perlukan adalah yang mudah dilakukan, biaya murah dan mampu memberi manfaat yang menguntungkan.
Teknologi bio proses berupa tekhnologi fermentasi pakan yang diberikan dalam program vucer ini adalah tekhnologi yang tepat bagi mereka, dimana dalam pemberian pakan itiknya mereka juga memanfatkan limbah yang belum diolah atau diperkaya sebagai bahan pakan (non enrichment). Melalui tekhnologi fermentasi pakan limbah mampu ditingkatkan nutrisinya terutama kandungan protein pakan. Dengan demikian kegiatan yang diberikan dalam program vucer ini sangat baik direspons mereka untuk meningkatkan kualitas nutrisi bahan pakan limbah udang yang mereka pakai selama ini. Kecenderungan antusisme peternak menerima secara baik pelatihan yang dilaksanakan dicerminkan oleh respons yang tinggi dalam ketepatan waktu kehadiran, kehadiran peserta dalam kegaiatn penyuluhan dan curah pendapat (brainstorming) dengan prosentase antara $90-100 \%$. Selain itu disisi lain terlihat dari keaktifan dalam mengemukakan ide dan gagasan, serta keberanian dalam bertanya cukup baik masing-masing dengan kisaran 70 - $90 \%$. Hasil akhir yang baik dari tahap ini adalah adanya peningkatan 
pemahaman dari pengetahuan dan skill mereka setelah pelatihan, ditunjukkan dengan meningkatnya nilai post test yang diberikan di akhir kegiatan pelatihan yang dilaksanakan dari $60-$ $70 \%$ meningkat menjadi $70-80 \%$.

\section{Tahap Demonstrasi pembuatan} limbah udang fermentasi

Pembuatan pakan fermentasi dengan materi utama bahan limbah udang terdiri kepala dan cangkang udang. Hasil kegiatan menunjukkan demo dan pembuatan limbah udang fermentasi dapat dilaksanakan oleh peserta dengan respons yang baik, pelaksanaannya dan tekhnologinya mudah dan biaya pembuatannya cukup murah. Pengelolaan saat pemeraman bahan fermentasi selama 4 hari

Kendala dan solusi yang harus diperhatikan dalam pembuatan limbah udang fermentasi adalah sebagai berikut :

1. Tekstur limbah udang yang terdiri dari kepala dan cangkang sangat keras, kasar dan cukup tajam, sehingga pencampuran dengan bahan dedak harus dilakukan dengan bantuan pengaduk kayu.

2. Untuk mengurangi kehilangan bobot limbah udang di dalam mesin karena ukuran saringan mesin yang tertentu, maka dianjurkan memberi alas kain kasa di atas saringan mesin sehingga potongan limbah udang yang kecil dapat terfermentasi semuanya.

3. Akibat kuatnya daya serap mesin pompa air untuk pembuangan air hasil fermentasi atau air cucian limbah udang saat awal dibersihkan , karena dekatnya jarak pompa dan mesin maka cara pembuangan air sisa dilakukan 2 cara, yaitu 1) air sisa hasil fermentasi yang jumlahnya lebih sedikit dibuang dengan bantuan keran pada pipa manual di bawah mesin, dan 2) sisa air cucian limbah udang segar yang lebih banyak di buang dengan bantuan pompa air

4. Pemeraman saat fermentasi berlangsung hingga panen di hari ke lima, panas yang terjadi meningkat secara kuadratik mulai hari ke-1 dan mencapai puncak pada hari ke 3 setelah itu mulai menurun lagi dan berhenti pada hari ke-5 saat panen. Untuk menghindari panas yang terlalu tinggi di atas $50^{\circ} \mathrm{C}$ yang dapat merusak hasil fermentasi maka 
dilakukan pembalikan sebanyak 2

kali sehari pada pagi dan sore hari. Panas yang terjadi disebabkan oleh aktifitas mikroorganisme (bakteri, protozoa, fungi) dalam merombak atau mendegradasi bahan fermentasi menjadi single cell protein .

5. Agar tidak berbahaya saat diberikan pada itik petelur, setelah panen pada hari ke-5, limbah udang fermentasi harus dianginanginkan dengan menjemur atau membuka tutup tempat fermentasi agar gas yang muncul sewaktu fermentasi berlangsung menguap dan setelah satu hari dapat disimpan di tempat lain dengan ventilasi yang baik untuk disimpan sebagai bahan baku pakan itik dalam campuran ransum.

\section{Pengujian nutrisi limbah udang sebelum dan setelah di fermentasi}

Nutrisi utama yang dianalisis adalah kadar protein untuk melihat peningkatan akibat single cell protein (SCP) yang terjadi selama fermentasi. Kadar nutrisi lain yang diukur adalah kadar air dan bahan kering (BK). Hasil ini untuk melihat seberapa besar manfaat adanya fermentasi dan performa mesin yang dibuat, selengkapnya hasil fermentasi limbah udang tersaji pada Tabel 2

Tabel 2. Hasil fermentasi limbah udang dengan mesin Anaerob Fermentation Machiner

\begin{tabular}{|c|c|c|c|}
\hline No & Parameter & $\begin{array}{c}\text { Sebelum } \\
\text { Fermentasi }\end{array}$ & Setelah Fermentasi \\
\hline \multicolumn{4}{|c|}{ Nutrisi } \\
\hline 1 & Kadar protein kasar $(\%)$ & 10.36 & 14.04 \\
\hline 2 & Kadar air (\%) & 19.84 & 22.15 \\
\hline 3 & Kadar bahan kering $(\%)$ & 80.16 & 77.85 \\
\hline \multicolumn{4}{|c|}{ Kualitas Fisik } \\
\hline 4 & Tekstur & Kasar dan keras & Lebih lunak \\
\hline 5 & Warna & Kemerahan & Merah kecoklatan \\
\hline 6 & $\mathrm{Bau}$ & Amis & Harum khas fermentasi \\
\hline 7 & Jamur patogen & Tidak ada & Tidak ada \\
\hline
\end{tabular}

Keterangan : Analisis nutrisi kadar PK, BK dan air dilakukan di Lab. Nutrisi PS Prod. Ternak UNLAM Banjarbaru 
Hasilnya menunjukkan manfaat adanya fermentasi dapat meningkatkan nutrisi pakan utamanya protein (PK) limbah udang sebesar $3.68 \%$ dari awalnya $10.36 \%$ menjadi $14.04 \%$ setelah fermentasi. Selain itu hasil fermentasi ini cukup baik karena mampu menurunkan kadar bahan kering (BK) pakan limbah udang dari $80.16 \%$ turun menjadi $77.85 \%$, hal ini menunjukkan sebagian BK pakan terutama karbohidrat bahan telah banyak terombak oleh bakteri pencerna serat menjadi single cell protein (SCP) atau protein murni yang apabila dianalisis terindikasikan sebagai protein kasar (PK).

Berdasarkan hasil pengamatan kualitas fisik pakan limbah udang fermentasi juga menunjukkan perbaikan fisik sebagai bahan pakan unggas seperti itik . Pengamatan menunjukkan perbaikan terjadi pada empat parameter meliputi tekstur, bau, warna dan jamur patogen. Tekstur pakan fermentasi limbah udang menjadi lebih lunak , warna menjadi sedikit kecoklatan akibat fermentasi dedak yang dicampur untuk sumber nutrisi mikroba dari EM-4, berbau harus khas fermentasi seperti tape dari sebelumnya berbau amis serta tidak dijumpai adanya jamur patogen yang berbahaya pada ternak itik. Dengan demikian keseluruhan hasil pakan fermentasi limbah udang cukup baik memberi manfaat yang besar bagi peningkatan nutrisi dan kualitas fisik bahan, yang mengindikasikan bahwa mesin fermentasi yang digunakan yaitu "An aerob fermentation machiner" hasil program Vucer ini cukup baik performanya.
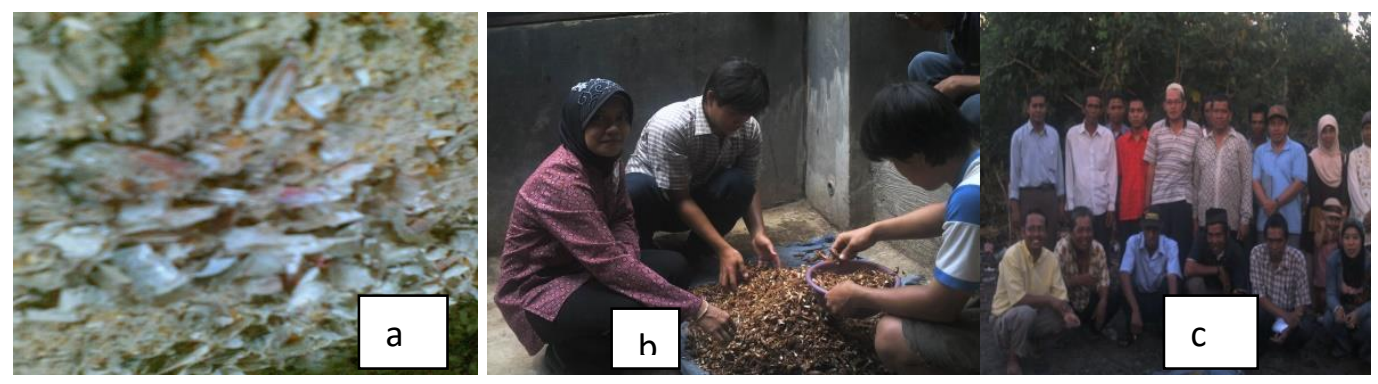

Foto Kegiatan : (a) Limbah Udang, (b) Demontrasi Pembuatan Pakan fermentasi (c). Tim pelaksana dan kelompok ternak 


\section{KESIMPULAN}

Simpulan dari kegiatan pengabdian ini dapat membantu meningkatkan ketrampilan petani/ peternak dalam inovasi baru teknologi pengolahan limbah udang sebagai pakan ternak Itik yang memiliki kualitas nutrisi cukup tinggi

\section{DAFTAR PUSTAKA}

Anonim. 2017. Laporan Village Breeding Centre Itik. Dinas Peternakan Daerah Tingkat I Kalimantan Selatan.

Biyatmoko, D. Dan T Rostini 2016. The Effect of protease enzyme eggs of Alabio Duck. International Journal of Biociensis, Vol 8 (2) p 202-208

Biyatmoko

D. 2002. InternationalPenggunaan ampas sagu fermentasi dalam ransum itik Alabio jantan (Disertasi). Bogor : Institut Pertanian Bogor, Program Studi Ilmu Ternak, Program Pascasarjana.

Biyatmoko, D. 2012. Laporan Konsultan Itik : Desains Pengembangan Itik Tahun 2006 2010 di Kalimantan Selatan. Dinas Peternakan Dati I Kalimantan Selatan.

Fauzi, B. 1994. Itik Alabio perlu penanganan lebih lanjut. Kompas, 5 September 1994.

Fardiaz, S. 1988. Fisiologi Fermentasi Teknologi Pangan dan Gizi. Pusat Antar Universitas Institut Pertanian Bogor. Bogor

Harjosworo, P. , dan Rukmiasih. 2003. Itik , Permasalahan dan
Pemecahan. Penebar Swadaya, Jakarta.

Istiana, E.S. Rohaeni dan Salfina. 1997. Pola pakan dan identifikasi pakan lokal untuk itik Alabio di Kalimantan Selatan. Kalimantan Scientiae No. 43 dan 44 Vol Januari - Maret 1997. Banjarbaru.

North, M.O., and D.D. Bell. 1997. Commercial Chicken Production Manual. $5^{\text {th }}$ Ed. Van Nostrand Reinhold, New York.

Purwadaria,T., J. Darma, E. Wina dan T. Haryati. 2009. Pengaruh fermentasi A. Niger terhadap sorgum dan daun kaliandra. Prosiding Pertemuan Ilmiah Tahunan Perhimpunan Mikrobiologi Indonesia di Bogor.

Rostini T. 2017. Inoculan Differences in the Quality Of Physical and Nutrition quality palm fermentation fronds as animal feed. J. IOSR-JAVS : 10 (1) : 29-32

Rohaeni, S. ,D. Biyatmoko, Jumar. 1997. Profil usaha peternakan itik Alabio di Kalimantan. Kalimantan Scientiae Vol JanuariMaret No. 43 \& 44, 1997. Univ. Lambung Mangkurat. Anggota tim.

Statistika Peternakan. 2018. Dinas Peternakan Propinsi Kalimantan Selatan.

Sulistyaningsih. 2005. Perkembangan dan Permasalahan Usaha Ternak Itik alabio di Kalimantan Selatan. Makalah Focus Group of Discussion (FGD) Komoditi Itik di Kalimantan Selatan. Dinas Peternakan kab. Hulu Sungai Utara (HSU). 
Utomo. 2014. Optimalisasi Pemanfaatan Itik Alabio Jantan sebagai Penghasil Daging. IPPTP. Banjarbaru. Hal. 13 16.

Winarno, F.G., S. Fardiaz dan D. Fardiaz. 1980. Pengantar Teknologi Pangan. Gramedia, Jakarta.

Wizna ,E.M., Maria,S.N., Rusmana, Adrizal dan Y. Rizal. 2007. Pemanfaatan sagu cincang pengganti jagung dalam ransum itik lokal periode layer. Prosiding Seminar Nasional II, Ilmu Nutrisi dan makanan Ternak, Fapet IPB. 15 - 16 Juli 2007. Hal. 107 108.

Yu,B., C.C. Tsai, J. C. Hsu and P.W.S. Chiou. 2014. Effect of different source of dietary iber on growth performance, intestinal morphology and caecal carbohydrates of domestic geese. Brit. Poult. Sci. 39 : 560 - 567. 